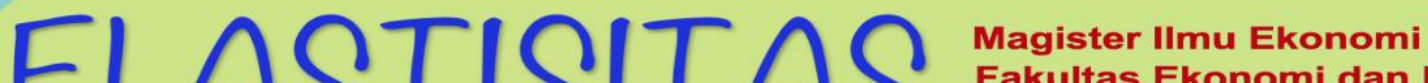 Fakultas Ekonomi dan Bisnis Universitas Mataram

\section{Analisis Penerimaan Dan Penyaluran Keuangan Dana Zakat Infaq Dan Shadaqah Melalui Badan Amil Zakat Nasional (Baznas) Kota Mataram}

\author{
Muhammad Irwan ${ }^{1 *}$, Titiek Herwanti ${ }^{1}$ dan Muaidy Yasin ${ }^{1}$ \\ ${ }^{1}$ Prodi Magister Ilmu Ekonomi, Fakultas Ekonomi dan Bisnis, Universitas Mataram \\ *email korespondensi : dae.wan65@yahoo.com
}

Info Artikel

Kata Kunci:

Penerimaan Zakat, Penyaluran Zakat, Infaq dan Shadaqah

\section{ABSTRAK}

Penelitian ini bertujuan untuk mendeskripsikan Tingkat Realisasi Pengumpulan dan Penyaluran dana, Perkembangan dana dihimpun dan disalurkan, dan Sistem pengumpulan dan penyaluran dana Zakat, Infaq dan Shadaqah (ZIS) yang dilakukan oleh Badan Amil Zakat Nasional (BAZNAS) Kota Mataram. Metode Penelitian yang dipergunakan adalah metode deskriptif, data yang dipergunakan data sekunder dan alat analisisnya adalah analisis pertumbuhan.

Hasil penelitian menunjukkan bahwa Badan Amil Zakat Nasional (BAZNAS) Kota Mataram berfungsi sebagai lembaga yang mengelola dana Zakat, Infaq dan Shadaqah (ZIS) dengan bertindak sebagai amil yang menerima dan menyalurkan dana tersebut kepada pihak yang berhak menerimanya. Wujud dari Pengelolaan Dana Zakat, disusun dalam bentuk Laporan Keuangan yang dibuat setiap tahun dibawah pengawasan dari Akuntan Publik. Sumber dana zakat yang dihimpun berasal dari pegawai SKPD se Kota Mataram, muzakki perorangan dan Badan Usaha. Realisasi zakat yang dapat dihimpun masih lebih rendah dari potensi yang ada. Dana ZIS yang disalurkan terus mengalami peningkatan, Dana telah disalurkan kepada golongan yang berhak menerimanya melalui program Ekonomi, Pendidikan, Dakwah, Kesehatan dan sosial kemanusiaan. Bentuk pengeluaran yang dilakukan oleh BAZNAS Kota Mataram adalah Pengeluaran/Penyaluran ZIS, Penggunaan Dana Pengelola, Penggunaan Bagi Hasil /Jasa Bank. Sistem Pengelolaan Zakat oleh BAZNAS Kota Mataram telah mengikuti petunjuk yanfg diatur dalam UU Zakat No 23 Tahun 2011 dengan melakukan konvigurasi sesuai dengan kondisi yang terjadi di masing - masing daerah. Pertanggungjawaban pengelolaan keuangan dalam bentuk laporan keuangan pada tahun 2017 mendapat prestasi wajar dari lembaga akuntan publik. 


\section{Elastisitas - Jurnal Ekonomi Pembangunan \\ Vol. 1 No. 1, (2019), 37 - 53}

\section{PENDAHULUAN}

\subsection{Latar Belakang}

Pembangunan manusia yang berkualitas merupakan salah satu bagian yang tidak terpisahkan dari proses pembangunan nasional, yang tentunya membutuhkan biaya yang relatif besar. Oleh karenanya, pemerintah telah dan tengah berusaha semaksimal mungkin untuk meningkatkan pendapatan nasional baik yang diperoleh negara maupun pihak - pihak swasta maupun masyarakat. Salah satu sumber keuangan suatu negara di samping berasal dari penerimaan negara berupa pajak, tetapi juga datang dari dana umat beragama dalam hal ini agama Islam.di antaranya adalah Zakat. Zakat merupakan kewajiban yang dibebankan kepada seseorang yang telah tergolong muzakki, yaitu orang yang telah memiliki harta benda atau pendapatan yang melebihi nishab yaitu setara nilai 85 gram emas dan telah mencapai haul yaitu usia selama satu tahun. Perintah zakat disamping wujud dari pengabdian seorang hamba yang berhubungan langsung dengan Allah SWT (hubungan vertikal) juga memiliki hubungan secara horisontal sesama manusia selama melaksanakan kehidupannya di dunia.

Pemerintah telah menetapkan dan membentuk suatu lembaga khusus yang menangani dana zakat termasuk infaq maupun sedekah.Kehadiran Undang Undang No 23 Tahun 2011 telah mengatur sentralisasi pengelolaan Zakat dan sepenuhnya dilakukan oleh negara. Hadirnya Undang - Undang ini diharapkan potensi zakat dapat direalisasikan dengan jumlah yang besar, serta dapat diketahui dengan pasti sistem pengelolaannya. Badan Amil Zakat Nasional (BAZNAS) yang menjadi lembaga utama yang melaksanakan pengelolaan Zakat, diharapkan mampu dan dapat menghimpun dana Zakat ini seoptimal mungkin dan mampu memberikan pertanggungjawaban secara terbuka dan transparan kepada para muzakki dan masyarakat secara umum. Dengan adanya pengelolaan yang baik serta transparansi maka para muzakki akan semakin tinggi tingkat kepercayaannya kepada BAZNAS untuk tempat menyalurkan Zakat.

Badan Amil Zakat Nasional (BAZNAS) yang telah berada di berbagai wilayan baik provinsi maupun kabupaten/kota, juga telah berikhtiar untuk memberikan pemahaman dan kesadaran kepada masyarakat khususnya yang sudah tergolong muzakki untuk mengeluarkan zakat dan menyalurkannya kepada Badan Amil Zakat Nasional (BAZNAS) setempat. Eksistensi Badan Amil Zakat Nasional (BAZNAS) sebagai wakil pemerintah untuk mengelola Zakat adalah mengimplementasikan perintah Allah dalam surat At-Taubah 103 yang artinya Ambillah zakat dari sebagian harta mereka, dengan zakat itu kamu membersihkan dan mensucikan mereka dan mendoalah untuk mereka. Sesungguhnya doa kamu itu (menjadi) ketenteraman jiwa bagi mereka. Dan Allah Maha Mendengar lagi Maha Mengetahui.

Badan Amil Zakat Nasional (BAZNAS) Kota Mataram sebagai perpanjangan tangan dari Badan Amil Zakat Nasional (BAZNAS) Pusat maupun Provinsi telah berikhtiar untuk menghimpun dana dari umat Islam baik berupa Zakat sebagai kewajiban juga Infaq maupun Sedekah (ZIS). Badan Amil Zakat Nasional (BAZNAS) Kota Mataram sebagai lembaga yang mengelola keuangan publik Islam tetap melakukan upaya terbaik untuk mensosialisasikan diri kehadapan Muzakki. Hal ini dilakukan untuk memberikan pemahaman kepada masyarakat tentang tugas dan kewajiban Badan Amil Zakat Nasional (BAZNAS) sebagai pengelola dana publik, baik berupa Zakat, Infaq maupun Shadaqah (ZIS). Pengetahuan dan pemahaman yang 


\section{Elastisitas - Jurnal Ekonomi Pembangunan \\ Vol. 1 No. 1, (2019), 37 - 53}

telah dimiliki masyarakat akan berdampak pada keinginannya untuk menyetorkan Zakat nya ke lembaga tersebut sembari mengurangi pengeluaran yang dilakukan secara individual.

Pengelolaan keuangan publik berupa zakat, infaq dan shadaqah (ZIS) harus dilakukan secara cermat, tepat dan hati-hati. Badan Amil Zakat Nasional (BAZNAS) harus mampu menjamin dan memberi kepastian bahwa seluruh dana masyarakat (muzakki) yang diterima harus tercatat dalam sistem keuangan (akuntansi). Sistem pengelolaan keuangan yang baik oleh lembaga publik termasuk Badan Amil Zakat Nasional (BAZNAS) mencerminkan kemampuan dan kinerja lembaga tersebut dalam mengelola dana yang bersumber dari masyarakat. Jika kinerja memberikan hasil yang baik, akan semakin mendapat amanah dan kepercayaan dari masyarakat untuk mengelola dana masyarakat dalam hal ini dana Zakat, Infaq dan Shadaqah (ZIS) sumber - sumber keuangan Islam.

Laporan keuangan merupakan salah salu bentuk tanggung jawab pelaksana suatu organisasi atau lembaga agar dapat diketahui kinerjanya. Menurut Mahmudi (2016) Laporan keuangan disajikan kepada pemangku kepentingan bukan untuk mempersulit dan membingungkan pembacanya tetapi justru membantu mereka untuk membuat keputusan sosial, politik dan ekonomi sehingga keputusan yang dibuat bisa lebih berkualitas. Laporan keuangan dipublikasikan tidak lebih seperti berita atau informasi di media massa, sehingga membaca laporan keuangan pada dasarnya tidaklah lebih sulit dibandingkan membaca berita - berita lain yang dimuat di koran, majalah, atau tabloid, meskipun laporan keuangan bukan satu-satunya informasi sebagai dasar untuk membuat keputusan. Berdasarkan laporan keuangan tersebut, dapat dilakukan analisis tentang capaian yang diperoleh dari kinerja organisasi atau lembaga yang bersangkutan.

Badan Amil Zakat Nasional (BAZNAS) Kota Mataram sebagai wujud pertanggung jawabannya kepada publik (muzakki) selalu membuat laporan keuangan setiap tahunnya, dengan tujuan untuk menginformasikan arus masuk dan keluar dalam ikhtiarnya mengumpulkan dana ZIS dari umat Islam yang telah memiliki kelebihan harta maupun pendapatannya. Hal ini juga sebagai wujud dari implementasikan firman Allah yang terdapat dalam surat Al-Baqarah ayat 282 yang memerintahkan kepada manusia yang melakukan kegiatan muamalah wajib mencatat segala kegiatan transaksi yang berkenaan dengan keuangan maupun pinjam meminjjam.

Atas dasar hal itulah, maka penelitian ini dilaksanakan dengan tujuan untuk mengetahui : (1) Tingkat Realisasi Pengumpulan dan Penyaluran dana Zakat, Infaq dan Shadaqah (ZIS) oleh Badan Amil Zakat Nasional (BAZNAS) Kota Mataram tahun 2012 - 2017; (2) Perkembangan dana Zakat, Infaq dan Shadaqah (ZIS) yang telah dihimpun dan disalurkan oleh Badan Amil Zakat Nasional (BAZNAS) Kota Mataram tahun 2012 - 2017; (3) Sistem pengumpulan dan penyaluran dana Zakat, Infaq dan Shadaqah (ZIS) yang dilakukan oleh Badan Amil Zakat Nasional (BAZNAS) Kota Mataram.

\section{TINJAUAN PUSTAKA}

\subsection{Laporan Keuangan}

Laporaan keuangan merupakan salah satu cara untuk memberikan informasi kepada masyarakat umum berkenaan dengansuatu kegiatan yang telah dilakukan dalam jangka waktu tertentu. Membuat laporan keuangan merupakan suatu keniscayaan bagi lembaga - lembaga publik untuk dapat mengetahui kemampuan kinerjanya dalam priode tersebut. Terdapat 2 alasan 


\section{Elastisitas - Jurnal Ekonomi Pembangunan \\ Vol. 1 No. 1, (2019), 37 - 53}

yang mendasari pentingnya laporan keuangan yaitu (Mahmudi, 2016) :

1. Dari sisi internal, laporan keuangan merupakan alat pengendalian dan evaluasi kinerja baik lembaga pemerintah maupun lembaga swasta dan lembaga - lembaga publik lainnya. Laporan keuangan merupakan bentuk pertanggungjawaban internal, yaitu pertanggungjawaban pada satuan kerja masing - masing lembaga.

2. Dari sisi pemakai ekternal, laporan keuangan merupakan bentuk pertanggungjawaban eksternal, yaitu pertanggungjawaban kepada masyarakat, serta pihak - pihak lain yang berkepentingan dengan laporan tersebut sebagai dasar untuk pengambilan keputusan ekonomi, sosial dan politik.

Laporan keuangan disusun bertujuan untuk menyediakan informasi yang menyangkut posisi keuangan, kinerja dan perubahan posisi keuangan suatu perusahaan atau lembaga yang bermafaat bagi sejumlah besar pemakai dalam pengambilan keputusan ekonomi. Informasi mengenai posisi keuangan, kinerja dan perubahan posisi keuangan sangat diperlukan untuk dapat melakukan evaluasi atas kemampuan perusahaan (lembaga) dalam menghasilkan kas (dan setara kas), dan waktu kepastian dari hasil tersebut. Posisi keuangan perusahaan dipengaruhi oleh sumber daya yang dikendalikan, struktur keuangan, likuiditas dan solvabilitas serta kemampuan beradaptasi dengan perubahan lingkungan (Prastowo, 2015).

$$
\text { Manfaat Pelaporan }
$$

Keuangan di antaranya (1) Memberikan informasi keuangan untuk menentukan dan memprediksi kondisi kesehatan keuangan lembaga - lembaga pemerintah terkait dengan likuiditas dan solvabilitasnya; (2) Memberikan informasi keuangan untuk menentukan dan memprediksi kondisi ekonomi suatu lembaga pemerintahan dan perubahanperubahan yang telah dan akan terjadi; (3) Memberikan informasi keuangan untuk memonitor kinerja, kesesuainnya dengan peraturan - peraturan perundang undangan, kontrak yang telah disepakati dan ketentuan lain yang disyaratkan.

Analisis adalah suatu penguraian atas suatu pokok atas berbagai bagiannya, dan penelaahan bagian itu sendiri serta hubungan antar bagian, dengan tujuan untuk memperoleh pengertian yang tepat dan pemahaman arti keseluruhan (Prastowo, 2015). Analisis diartikan juga sebagai kemampuan memecahkan atau menguraikan suatu materi atau informasi menjadi komponen-komponen yang lebih kecil sehingga lebih mudah dipahami. Yaitu usaha dalam mengamati sesuatu secara mendetail dengan cara menguraikan komponen pembentuknya atau menyusun sebuah komponen untuk kemudian dikaji lebih mendalam.

Laporan keuangan yang telah disusun oleh berbagai pihak yang berkepentingan dapat dianalisis lebih lanjut, agar dapat diketahui kinerja dari perusahaan atau lembaga yang membuat laporan keuangan tersebut. Sebelum dilakukan analisis, seorang analis harus mempunyai gambaran aktivitas perusahaan atau lembaga yang tercermin dalam laporan tersebut agar hasil analisis yang dilakukan dapat memuaskan berbagai pihak. Analis juga harus mempunyai kemampuan atau kebijakan yang cukup baik dalam mengambil suatu kesimpulan, di samping harus memperhatikan dan mempertingmbangkan perubahan perubahan kondisi perusahaan atau lembaga dan perubahan tingkat harga. Langkah - langkah dalam analisis laporan keuangan adalah mengorganisasi, mengumpulkan data yang diperlukan, 


\section{Elastisitas - Jurnal Ekonomi Pembangunan \\ Vol. 1 No. 1, (2019), 37 - 53}

mengukurnya, menganalisis dan menginterpretasikan (Najmudin, 2011).

Metode atau teknik analisis digunakan untuk menentukan dan mengukur hubungan antara pos-pos yang tedapat dalam laporan keuangan sehingga dapat diketahui perubahan - perubahan setiap pos tersebut bila dibandingkan dengan laporan dari beberapa priode untuk satu perusahaan atau lembaga tertentu. Tujuan setiap priode analisis adalah untuk menyederhanakan data agar dapat lebih dimengerti sehingga dapat digunakan sebagai dasar pengambilan keputusan bagi pihak yang membutuhkan (Najmudin, 2011).

\subsection{Zakat}

Zakat menurut kaidah bahasa (etimologi) berasal dari kata Adz-Dzaka yang berarti suci, $A n$-nama' yang berarti tumbuh (mengalami pertumbuhan) dan Adz-Dziyadah artinya berkembang atau bertambah (mengalami pertambahan). Adapun maksud dari beberapa makna tersebut adalah perbaikan dan penyucian hati jiwa manusia, melalui ilmu yang bermanfaat dan amal salih dengan bertaqwa kepada Allah SWT (Wijayanti, dkk, 2008, 31-32). Zakat menurut kaidah syariat (terminologi) berarti, sejumlah harta tertentu yang diwajibkan oleh Allah SWT untuk diberikan kepada para mustahik yang disebutkan dalam Al-Qur'an atau juga berarti sejumlah tertentu dari harta tertentu yang dikeluarkan oleh orang orang yang telah memenuhi syarat zakat (muzakki) diberikan untuk orang tertentu. Dari istilah fiqh zakat berarti sejumlah harta tertentu yang diwajibkan Allah diserahkan kepada orang yang berhak di samping berarti mengeluarkan jumlah tertentu itu sendiri (Qardawi, 1996, 34).

Menurut Ali $(1988 ; 26)$ dan AshShiddieqy (1991;30), zakat menurut garis besarnya dibagi dua yaitu : (1) Zakat Mal (Zakat harta) yakni bagian dari harta kekayaan seseorang (termasuk badan hukum) yang wajib dikeluarkan untuk golongan orang-orang tertentu setelah dimiliki dalam jangka waktu tertentu dan jumlah minimal tertentu seperti zakat emas, perak, binatang, tumbuh-tumbuhan (buah-buahan dan biji-bijian) dan barang perniagaan. Fuqaha kontemporer membagi harta dan memasukan yang wajib dizakati ketika syarat-syaratnya telah terpenuhi dalam beberapa jenis (Fakhruddin, 2008; 39) yaitu : (a) Harta yang dirinya sendiri dan pertumbuhannya wajib dizakati, seperti barang-barang dagangan, barang-barang industri, kekayaan moneter, investasi dan aktivitasaktivitas kontemporer yang sejenis; (b) Harta yang dirinya wajib dizakati, seperti rikaz,(harta karun), hasil pertanian, buahbuahan dan al-mal al-mustafad (harta yang diperoleh). (2) Zakat nafs, yakni zakat jiwa yang dinamai juga dengan zakat fithri (zakat yang diberikan berkenaan dengan akan selesainya ibadah puasa yang difardhukan).

Pengelolaan Zakat sudah dilaksanakan oleh negara sejak awal pemerintahan maupun pertengahan Islam hingga saat sekarang, meskipun masih banyak para muzakki mengeluarkan dan menyalurkan sendiri dana zakatnya. Keterlibatan negara atau pemerintah dalam pengelolaan zakat karena mengandung beberapa manfaat yaitu (Doa, 2005) : (1) Kelompok masyarakat yang lemah dan kekurangan tidak merasa hidup dibelantara, tempat berlakunya hukum rimba, dimana yang kuat menggilas yang lemah. Sebaliknya, mereka merasa hidup di tengah manusia yang beradab, memiliki nurani, kepedulian dan tradisi saling menolong. (2) Para muzakki, lebih disiplin dalam menunaikan kewajibannya dan kaum fakir miskin lebih terjamin haknya. (3) Fakir miskin lebih terjaga, karena dia tidak lagi seperti peminta-minta. (4) Distribusinya akan lebih tertib dan teratur (5) 
Peruntukan bagi kepentingan umum, seperti fii sabilillah dapat disalurkan dengan baik, karena pemerintah lebih mengetahui sasaran dan pemanfaatannya.

(6) Zakat dapat mengisi perbendaharaan negara (7) Zakat dapat dipergunakan untuk mengelola dan mengembangkan potensi -potensi ekonomi rakyat yang bersifat produktif, seperti membuka lapangan kerja dari usaha yang diambil dari dana zakat atau memberikan bantuan modal untuk membuka usaha mandiri. (8) Menghilangkah rasa rikuh dan canggung yang mungkin dialami oleh mustahiq ketika berhubungan dengan muzakki (orang yang berzakat).

\section{METODE PENELITIAN}

\subsection{Jenis Penelitian}

Jenis penelitian yang dipergunakan dalam penelitian ini adalah penelitian deskriptif yang mendeskripsikan dan memberikan gambaran tentang Perkembangan penerimaan dan penyaluran keuangan dana zakat oleh BAZNAS Kota Mataram. Hal ini dimaksudkan memberikan informasi dan gambaran yang jelas berkenaan dengan kemampuan BAZNAS Kota Mataram dalam mengelola dana Zakat termasuk Infaq dan Shadaqah (ZIS) yang tertuang dalam bentuk laporan keuangan.

\subsection{Lokasi Penelitian}

Penelitian dilakukan di kota Mataram dengan menfokuskan kajian pada kegiatan penerimaan dan penyaluran ZIS oleh BAZNAS Kota Mataram tahun 2012 - 2017. Kota Mataram secara sengaja dijadikan lokasi penelitian dengan pertimbangan bahwa kota Mataram merupakan pusat aktivitas baik pemerintahan, pendidikan maupun perekonomian, sehingga memiliki potensi besar sebagai sumber keuangan Islam yang diperoleh dari dana Zakat termasuk Infaq dan Shadaqah..

\subsection{Jenis Dan Sumber Data}

Penelitian ini sepenuhnya menggunakan data sekunder yang bersumber Laporan Realisasi Keuangan BAZNAS Kota Mataram sejak tahun 2012 2017. Disamping itu dibutuhkan data yang berkenaan dengan ZIS baik secara nasional maupun provinsi NTB yang bersumber dari berbagai buku literature dan informasi yang berkaitan dengan analisis penelitian ini.

\subsection{Teknik Analisis Data}

Untuk mencapai tujuan analisis ini, analisis dilakukan secara kualitatif dan kuantitatif. Untuk mengetahui perkembangan penerimaan, penyaluran dana ZIS dan jumlah penduduk miskin di Kota Mataram dipergunakan analisis pertumbuhan sebagai berikut (Kuncoro ,2013) :

$\operatorname{Rog}=\left(\mathrm{PZ}_{\mathrm{ti}}-\mathrm{PZ} \mathrm{Z}_{\mathrm{t}-1} / \mathrm{PZ} \mathrm{t}_{\mathrm{t}-1} \times 100 \%\right.$

Dimana : $\mathrm{PZ}_{\mathrm{t}}=$ Penerimaan dan Penyaluran ZIS pada tahun $t$;

$\mathrm{PZ}_{\mathrm{t}-1}=$ Penerimaan dan Penyaluran ZIS pada tahun $\mathrm{t}-1$

\section{$\mathrm{i}=$ tahun $2012-2017$}

Sedangkan untuk mendapatkan laju pertumbuhan ekonomi rata - rata per tahun, menggunakan rumus sebagai berikut (Tambunan, 2014) :

$$
\left.\mathrm{r}=\left[\left(\sqrt[n-1]{\frac{t n}{t o}}\right)-1\right] \times 100 \%\right]
$$

atau dengan faktor penggabungan :

$$
t_{n}=\text { to }(1+r)^{n-1}
$$

Dimana :

$\mathrm{r}$ = laju pertumbuhan rata - rata per

tahun; $\mathrm{n} \quad=$ jumlah tahun;

tn = tahun terakhir periode;

to $=$ tahun awal periode;

$(1+r)^{n-1}=$ menggambarkan faktor penggabungan

\section{HASIL DAN PEMBAHASAN}

\subsection{PENGELOLAAN DANA ZAKAT}

Zakat merupakan rukun Islam yang ketiga setelah sholat yang memiliki peran yang sangat penting dalam menata kehidupan manusia untuk menuju kualitas yang lebih baik. Zakat sebagai 


\section{Elastisitas - Jurnal Ekonomi Pembangunan \\ Vol. 1 No. 1, (2019), 37 - 53}

salah satu bentuk muamalah, merupakan variabel utama dalam ekonomi Islam untuk menciptakan perekonomian negara menjadi stabil. Zakat merupakan salah satu bentuk keberpihakan orang yang mampu (kaya) kepada orang yang tidak mampu (miskin) dengan mendistribusikan hartanya menurut ketentuan yang telah ditetapkan (nishab). Aliran dana yang bersumber dari orang yang mampu (kaya) akan merangsang orang yang tidak mampu (miskin) melakukan aktivitas ekonomi baik bertindak sebagai produsen maupun konsumen. Peningkatan aktivitas ekonomi ini berdampak pada semakin bergairahnya transaksi barang maupun jasa. Zakat seharusnya dapat memberikan kontribusi besar dalam pemberdayaan umat dan kesejahteraan negeri ini jika dikelola dengan baik. Untuk mencapai hal itu, dibutuhkan konsensus dan visi bersama dari seluruh stakeholders zakat nasional untuk membangun zakat masa depan. Visi zakat nasional ini semestinya dibangun dengan bersumber pada cita cita besar, tantangan utama dan faktor faktor yang sangat mempengaruhi kinerja pengelolaan zakat nasional (Wibisono, 2015).

Pemerintah menyadari sepenuhnya besarnya potensi dana yang berasal dari umat Islam yang dapat dijadikan sebagai sumber pembiayaan pembangunan bangsa. Potensi dana yang besar ini harus dapat digali dan dikelola dengan baik sehingga benar-benar terarah dan tepat untuk mencapai sasaran yang dituju. Oleh karenanya, pemerintah berkewajiban untuk mengelola dana zakat ini oleh suatu lembaga resmi yang dibentuk oleh Pemerintah. Yusuf Qardhawi dalam Doa (2001) mengatakan bahwa ada lima alasan mengapa zakat harus dikelola oleh negara yaitu (1) Nurani kebanyakan orang telah mengeras, akibat cinta dunia yang berlebihan, maka bila hak fakir miskin digantungkan kepada orang semacam itu, kesejahteraan mereka tidak akan terjamin; (2) Kehormatan kaum miskin dapat terpelihara dan terhindar dari cacian pemberi; (3) Distribusinya bisa lebih tertib dan menyeluruh; (4) Penerima zakat tidak hanya fakir miskin, tapi ada juga yang berhak menerima demi kemasalahatan umum, seperti muallaf, jihad fisabilillah, dan dakwah; (5) Zakat dapat mengisi perbendaharaan negara.

Kewenangan negara yang berhak mengelola Zakat didasarkan pada firman Allah SWT dalam surat At-Taubah ayat 103 yang berbunyi :

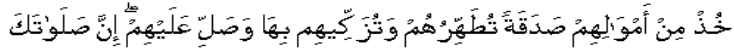

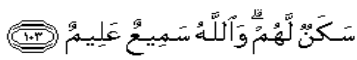
Ambillah zakat dari sebagian harta mereka, dengan zakat itu kamu membersihkan dan mensucikan mereka dan mendoalah untuk mereka. Sesungguhnya doa kamu itu (menjadi) ketenteraman jiwa bagi mereka. Dan Allah Maha Mendengar lagi Maha Mengetahui.

Rasulullah SAW bersabda : Beritahukanlah kepada mereka bahwa Allah telah mewajibkan dari sebagian harta mereka untuk disedekahkan, diambil dari orang kaya di antara mereka dan dikembalikan kepada kaum fakir miskin di kalangan mereka. Bila mereka mentaatimu dalam hal ini, maka peliharalah kedermawanan hartaa mereka dan takutlah akan do'a orang yang teraniaya. Sungguh tidak ada penghalang antara do'a mereka dengan ALLAH (HR. Jama'ah dari Ibn Abbas).

Perintah ambillah zakat bermakna bahwa pengelolaan zakat perlu melibatkan kekuasan yang berkuasa "mengambil" yaitu pemerintah. Dengan dikelola oleh pemerintah, zakat dapat memainkan peranannya sebagai sumber keuangan negara yang ikut berperan dalam mengatasi permasalahan ekonomi umat, khususnya dalam mengentaskan kemiskinan baik materi matupun spritual. Undang -Undang Zakat No 23 Tahun 2011 sebagai dasar hukum pelaksanaan 
pengelolaan zakat telah memberikan aturan yang jelas tentang tatacara pengelolaan zakat. Undang - Undang ini meskipun terdapat pro dan kotra atas kehadirannya, telah menetapkan bahwa yang berhak mengelola Zakat adalah BAZNAS baik ditingkat pusat maupun daerah. Menurut Undang - Undang ini, tujuan dari pengelolaan Zakat adalah :

1. Meningkatkan efektifitas dan efisiensi pelayanan dalam pengelolaan zakat.

2. Meningkatkan manfaat zakat, untuk mewujudkan kesejahteraan masyarakat dan penanggulangan kemiskinan.

Mengacu dari tujuan pengelolaan zakat ini secara kelembagaan, maka dapat memberikan hasil yang baik meski belum sepenuhnya tercapai. Menurut Do'a( (2005), Pengelolaan Zakat oleh Pemerintah Republik Indonesia memiliki banyak tujuan di antaranya : (1) Menghindari pungutan double pajak dan zakat; (2) Agar pengumpulan zakat dapat tertib dan optimal; (3) Agar Penyaluran zakat menjadi tepat sasaran dan produktif; (4) Mendidik umat Islam agar membayar zakat harta sesuai ketentuan Syariat Islam (adalah kewajiban pemimpin); Pemerataan pendapatan dan mengurangi keemnburuan sosial serta mengurangi tingkat kriminalitas.

\section{PENGELOLAAN DANA ZAKAT OLEH BADAN AMIL ZAKAT NASIONAL (BAZNAS) KOTA MATARAM}

Badan Amil Zakat Nasional (BAZNAS) Kota Mataram sebagai lembaga resmi yang bdibentuk oleh pemerintah, memiliki hak dan kewenangan mengelola dana zakat termasuk Infaq dan Shadaqah dari masyarakat muslim di NTB. Kepengurusan BAZNAS Kota Mataram telah mengalami beberapa kali pergantian pengurus, dan susunan kepengurusan terbaru berdasarkan Surat Keputusan
Walikota Mataram No. 531/1V/2016 tanggal 13 April 2016 Tentang Pengangkatan Pimpinan BAZNAS Kota Mataram. Kepengurusan ini telah melaksanakan tugas dan kewajibannya yang berlandaskan pada Tujuan BAZNAS Kota Mataram yaitu :

1. Mewujudkan Manajemen Pengelolaan Zakat, Infaq dan Shadaqah yang Transparan, Kredibel dan Akuntabel serta sesuai dengan Ketentuan Agama dan Peraturan Perundang Undangan yang berlaku;

2. Mempertanggung jawabkan pelaksanaan Kegiatan Pengumpulan, Pendistribusian dan Pendayagunaan Zakat, Infaq dan Shadaqah (ZIS) dan Dana Sosial Keagamaan Lainnya;

3. Memenuhi Ketentuan Pasal 29 Ayat (1) Unndang - Undang Nomor 23 Tahun 2011 tentang Pelaporan Pengelolaan Zakat.

Sasaran akhir yang dituju jika Zakat, Infaqdan Shadaqah (ZIS) dikelola secara kelembagaan, adalah para penerima Dana Zakat khususnya (mustahid) akan berubah menjadi orang yang mengeluarkan Zakat (Muzakki). Pendistribusian ZIS secara kelembagaan merupakan hal yang paling ideal, karena khususnya Zakat bila didistribusikan secara mandiri, meskipun alasan yang lebih mengemuka muzakki akan merasa puas dan zakatnya tersalurkan dalam waktu yang cepat. Namun hal ini tidak akan mampu merubah kualitas kehidupan mustahiq kepada kondisi yang lebih baik, karena dana yang diberikan besarnya relatif kecil.

\section{LAPORAN PENGELOLAAN} KEUANGAN OLEH BAZNAS KOTA MATARAM

Badan Amil Zakat Nasional (BAZNAS) Kota Mataram secara rutin menyusun laporan keuangannya yang dimasukkan sebagai salah satu komponen 


\section{Elastisitas - Jurnal Ekonomi Pembangunan \\ Vol. 1 No. 1, (2019), 37 - 53}

dalam Laporan Pengelolaan Zakat, Infaq dan Shadaqah pada tahun berjalan. Badan Amil Zakat Nasional (BAZNAS) Kota Mataram dalam menjalankan dan mengelola keuangan publik, mendapatkan pengawasan (audit) baik secara internal maupun ekternal. Pengawas (audit) internal berasal dari Pimpinan Badan Amil Zakat Nasional (BAZNAS) Kota Mataram, yang terdiri dari pengawasan manajemen dan kepatuhan internal dalam Pengelolaan Zakat. Dilain pihak masyarakat juga berperan untuk melakukan pengawasan dalam upaya untuk mengembangkan Pengeloaan Zakat, Infaq dan Shadaqah (ZIS). Pihak ekternal yang melakukan pengawasan (audit) adalah akuntan publik yang telah ditunjuk untuk melakukan pengawasan. Pada tahun 2016 Badan Amil Zakat Nasional (BAZNAS) Kota Mataram telah memperoleh hasil audit akuntan publik dengan predikat wajar.

Laporan keuangan yang telah disusun tentunya didasarkan pada prinsip prinsip akuntansi. Badan Amil Zakat Nasional (BAZNAS) Kota Mataram sebagai lembaga keuangan yang bergerak di bidang syariah, harus mengikuti kaidah - kaidah syariah sebagai halnya yang berlaku pada lembaga- lembaga keuangan syariah terutama lembaga perbankan Islam. Pernyataan Standard Akuntansi (PSAK) syariah telah berhasil diterbitkan oleh IAI yaitu PSAK tentang Akuntansi Perbankan Syariah No 59. PASK yang mulaui berlakuk ta Badan Amil Zakat Nasional (BAZNAS) Kota Mataram tahun 2008 merupakan Kerangka Dasar Penyusunan Dan Penyajian Laporan Keuangan. Kemudian PSAK ini disempurnakan lagi dan mulai berlaku pada tahun 2009 (Najmudin, 2011).

4.2. Tingkat Realisasi Pengumpulan Dan Penyaluran Dana ZIS oleh BAZNAS Kota Mataram tahun 2012 - 2017.

\subsubsection{Pengumpulan Zakat, Infaq Dan} Shadaqah (ZIS)

Badan Amil Zakat Nasional (BAZNAS) Kota Mataram merupakan salah satu lembaga yang dipercaya oleh Muzakki untuk menyalurkan zakat, infaq maupun sedekah kepada golongan - golongan (ahsnaf) yang berhak menerimanya. Sejak hadirnya UU No 23 Tahun 2011 sebagai penyempurnaan UU No 38 Tahun 1999. BAZNAS Kota Mataram telah melakukan berbagai penyesuaian dan melaksanakan kegiatannya berdasarkan UU No. 23 Tahun 2011 tersebut. Dana operasionalisasi BAZNAS Kota Mataram berasal dari bantuan pemerintah Daerah Kota Mataram. Di samping biiaya operasional, BAZNAS Kota Mataram juga mendapat dana bantuan sosial dan bantuan dari Kementerian Agama Provinsi Nusa Tenggara Barat.

Atas kepercayaan yang diberikan oleh Muzakki, BAZNAS Kota Mataram telah menerima dan menghimpun dana Zakat termasuk Infaq dan Shadaqah (ZIS) . Jumlah dana yang mampu dihimpun oleh BAZNAS Kota Mataram dari tahun ke tahun terus mengalami peningkatan, meskipun besarnya perubahan peningkatan dari tahun ke tahun tidak menunjukkan besar yang sama. Besarnya Penerimaan BAZNAS Kota Mataram dari berbagai sumber tersebut terlihat dalam tabel berikut.

Tabel 1. Total Penerimaan, Penerimaan ZIS dan Kontribusinya Terhadap Penerimaan

\begin{tabular}{|c|c|c|c|}
\hline Tahun & $\begin{array}{c}\text { Total Penerimaan } \\
(\mathrm{Rp})\end{array}$ & $\begin{array}{c}\text { Penerimaan ZIS dan } \\
\text { Lainnya (Rp) }\end{array}$ & $\begin{array}{c}\text { Persentase } \\
(\%)\end{array}$ \\
\hline 1 & 2 & 3 & $4=3 / 2 \times 100$ \\
\hline 2012 & 5.918 .506 .420 & 2.860 .162 .433 & 48,33 \\
\hline 2013 & 7.079 .049 .243 & 3.599 .430 .076 & 50,85 \\
\hline 2014 & 6.717 .849 .023 & 3.655 .584 .451 & 54,42 \\
\hline 2015 & 7.730 .958 .144 & 4.591 .840 .055 & 59,40 \\
\hline 2016 & 7.835 .705 .161 & 4.836 .062 .160 & 61,72 \\
\hline 2017 & 6.444 .496 .859 & 4.797 .496 .859 & 74,44 \\
\hline
\end{tabular}

Total Penerimaan BAZNAS Kota Mataram dari tahun ke tahun terus mengalami peningkatan terkecuali pada tahun 2014 dan 2017 mengalami penurunan. Hal ini mengindikasikan bahwa BAZNAS Kota 


\section{Elastisitas - Jurnal Ekonomi Pembangunan \\ Vol. 1 No. 1, (2019), 37 - 53}

Mataram memiliki tanggung jawab yang besar untuk menggali potensi dana yang berasal dari umat Islam sehingga membutuhkan dukungan dari berbagai pihak baik berkenaan dengan fasilitas kantor maupun fasilitas operasional. Oleh karenanya pada tahun 2012 dengan menggunakan dana bantuan Pemerintah Kota Mataram, mampu membeli sebuah kendaraan yang mempermudah operasionalisasi pengurus BAZNAS guna mewujudkan tujuan serta visi dan misinya. Bantuan operasionalisasi ini menjadi penerimaan rutin bagi BAZNAS Kota Mataram termasuk di dalamnya Santuan Beras panduduk lanjut usia (lansia) yang tergolong miskin.

Kontribusi yang diberikan oleh dana ZIS dan Lainnya terhadap total penerimaan BAZNAS Kota Mataram setiap tahunnya bervariatif dengan rata - rata kontribusi sebesar 58,19 persen. Hal ini bermakna bahwa BAZNAS Kota Mataram telah menjalankan tugasnya dengan baik karena mampu menghimpun penerimaan yang lebih besar dibanding dengan penerimaan non ZIS. Kontribusi ini diharapkan akan terus mengalami peningkatan dari tahun ke tahunnya, yang tentunya diimbangi dengan semakin bertambahnya masyarakat yang melaksanakan perintah agama ini baik Zakat sebagai kewajiban juga Infaq, Shadaqah dan amaliyah sunah lainnya. Atas dasar hal inilah BAZNAS Kota Mataram terus melakukan inovasi perencanaan kegiatan setiap tahunnya yang mengarah pada peningkatan penerimaan dana yang bersumber dari umat Islam yang bersifat sosial ini.

Zakat merupakan bentuk kepedulian sosial dari orang yang tergolong mampu dan memeliki harta yang berlebih, atas perintah Allah SWT wajib disalurkan kepada orang lain yang kondisinya masih tergolong kurang mampu ditinjau dari berbagai aspek. Zakat adalah sarana untuk menyucikan dan membersihkan jiwa manusia dari sifat kekikiran dan ketamakan terhadap keinginan mengeluarkan harta. Rasulullah SAW bersabda : "Sesungguhnya sedekah ( Zakat) itu tidak layak untuk keluarga Muhammad. Sesunngguhnya ia merupakan kotoran badan manusia..." (HR. Muslim). Semakin tinggi pemahaman masyarakat yang mampu terhadap hikmah zakat maka semakin tinggi kesadaran seseorang untuk mengeluarkannya.

Potensi dana yang besar dari umat Islam ini dapat dimanfaatkan untuk mempercepat proses pengembangan kualitas kehidupan manusia. Namun potensi tersebut belum mampu dihimpun secara maksimal karena adanya berbagai pandangan, sikap dan pemahaman yang berbeda di antara muzaki tentang penyaluran zakat, infaq maupun shadaqah. Potensi tersebut dapat bersumber dari Petani, Pedagang, Profesi maupun masyarakat umum yang tergolong kaya. Potensi zakat sebagai sumber keuanga Islam ini masih dibutuhkan kerja keras untuk menghimpunnya, belum termasuk sumber dana yang berasal dari infaq maupun shadaqah.

Menurut Ketua BAZNAS Kota Mataram bahwa potensi Zakat di Kota Mataram mencapai Rp 16 milyar lebih. Atas dasar potensi yang besar tersebut, BAZNAS Kota Mataram menargetkan penerimaan sebesar Rp 6.500.000.000,- namun hingga tahun 2017 potensi tersebut yang dapat dihimpun baru sebesar Rp 4,7 milyar atau sekitar 30 persen dari seluruh potensi atau sebesar 74,00 persen dari target yang telah direncanakan. Penerimaan dari Zakat ditargetkan sebesar Rp 2.400.000.000, yang mampu direalisasikan sebesar Rp 3.122.437.500,- (130,10 \%). Infaq/shadaqah ditargetkan Rp 2.400.000.000,- yang direalisasikan sebesar Rp 1.137.730.000,$(47,41 \%)$. Berdasarkan data ini, pada tahun 2017, BAZNAS Kota Mataram telah 


\section{Elastisitas - Jurnal Ekonomi Pembangunan \\ Vol. 1 No. 1, (2019), 37 - 53}

mampu memenuhi targetnya meskipun masih jauh lebih kecil dari potensi yang ada. Namun, penerimaan dari Infaq/Shadaqah masih lebih kecil dari target yang telah ditentukan sebelumnya Pemahaman masyarakat tidak hanya tertuju pada kewajiban untuk mengeluarkan zakat beserta syarat - syarat yang melekat di dalamnya, namun juga cara dan sistem penyalurannyapun harus dipahami. Masyarakat yang memahami bahwa penyaluran ZIS sebaiknya dikelola secara kelembagaan maka kana disalurkan melalui lembaga, sementara yang masih meyakini penyaluran secara individu yang terbaik maka ia akan menyalurkan sendiri ZISnya. Potensi zakat yang bersumber dari muzakki tidak sepenuhnya dapat dihimpun oleh BAZDA Kota Mataram melainkan hanya diperoleh dari Muzakki yang hanya memberikan zakatnya untuk dikelola oleh BAZDA Kota Mataram.

Jumlah terbanyak dari dana ZIS yang dapat dihimpun dan diterima oleh BAZNAS kota Mataram adalah berasal dari dana Zakat, Infaq dan shadaqah dari gaji profesi yang berasal dari Pegawai Negari Sipil (PNS) yang tersebar di berbagai Satuan Kerja Perangkat Daerah (SKPD) di wilayah administrasi Kota Mataram. Zakat, infaq maupun sedekah yang bersumber dari PNS ini adalah dana ZIS yang dipotong langsung oleh bendahara masing - masing SKPD dalam bentuk zakat profesi sebagai PNS termasuk infaq dan shadaqah. Kemudian dana ZIS ini oleh bendaharawan disetorkan kepada BAZNAS Kota Mataram.

Muzakki secara perorangan atau lembaga - lembaga non pemerintah lainnya yang memberikan kepercayaan kepada BAZNAS Kota Mataram untuk menyalurkan kepada para mustahiq masih relatif sedikit jumlahnya. Hal ini disebabkan karena di Kota Mataram telah ada juga lembaga - lembaga pengelola
Zakat atau Lembaga Amil Zakat (LAZ) seperti LAZ DASI Mataram yang juga melakukan kegiatan yang sama dengan BAZNAS Kota Mataram. Adanya lembaga - lembaga pengelola Zakat ini, menjadi alternatif bagi muzakki untuk menentukan pilihannya sebagai tempat untuk mengeluarkan zakat guna dikelola lebih lanjut oleh lembaga yang dipilihnya. BAZNAS Kota Mataram, terus berusaha untuk memberikan pemahaman dan meyakinkan Muzakki untuk memberikan kepercayaan dan amanah kepada BAZNAS Kota Mataram untuk mengelola dana ZIS. Setiap tahun BAZNAS Kota Mataram menyusun rencana kerja untuk terus meningkatkan penerimaan dana ZIS untuk dikelola dan diberikan kepada berbagai pihak yang berhak menerimanya. Salah satu kegiatan yang dilakukan adalah melakukan sosialisasi kepada seluruh komponen yang berkaitan langsung dengan ZIS. Intinya kegiatan sosialisasi dilakukan untuk memberikan motivasi kepada umat Islam agar melaksanakan kewajiban berzakat sesuai dengan Syariat Islam (Rukun Islam).

Kegiatan sosialisasi merupakan salah satu langkah yang dilakukan oleh Badan Amil Zakat Nasional (BAZNAS) Kota Mataram dalam upaya untuk optimalisasi Pengumpulan Zakat termasuk Infaq dan shadaqah. Langkah - langkah yang dilakukan untuk Optimalisasi Pengumpulan zakat adalah :

1. Metode Fundraising, Yaitu kegiatan penggalangan/pengumpulan dana zakat untuk kegiatan tertentu. Metode ini berupaya untuk optimalisasi pengelolaan zakat dari muzakki baik perorangan/perusahaan untuk memaksimalisasi penerimaan zakat.

Tujuan dari metode ini adalah menghimpun dana zakat, memperbanyak muzakki, meningkatkan citra lembaga pengelola zakat (BAZNAS), menghimpun 


\section{Elastisitas - Jurnal Ekonomi Pembangunan \\ Vol. 1 No. 1, (2019), 37 - 53}

simpatisan/relasi pendukung dan meningkatkan kepuasan para muzakki.

2. Metode Fundrasing, bilakukan dengan cara mempengaruhi, memberitahukan dan mengingatkan kepada umat Islam, guna dapat mendorong kesadaran dan kepedulian serta semangat untuk menunaikan zakat. Kegiatan kegiatan yang dilakukan adalah :

a. Sosialisasl langsung yang diwujudkan melalui ceramah, dakwah oleh tokoh - tokoh agama maupun tokoh - tokoh masyarakat.

b. Sosialisasi tidak langsung dilakukan melalui media elektronik maupun media buletin, baliho, surat kabar dan lain - lain

\subsubsection{Penyaluran Dana Zakat Infaq dan} Shadaqah (ZIS)

Zakat, Infaq dan Shadaqah yang telah dihimpun dari Muzakki akan disalurkan oleh BAZNAS kota Mataram sebagai lembaga yang diamanahkan kepada orang - orang yang berhak menerimanya atau mustahiq. BAZNAS Kota Mataram dengan kepercayaan yang diberikan tersebut, telah melakukan penyaluran dana Zakat termasuk Infaq dan Shadaqah dengan berbagai program yang telah dicanangkan. Jumlah dan total penyaluran juga mengalami fluktuasi sebagaimana terlihat dalam gambar berikut.

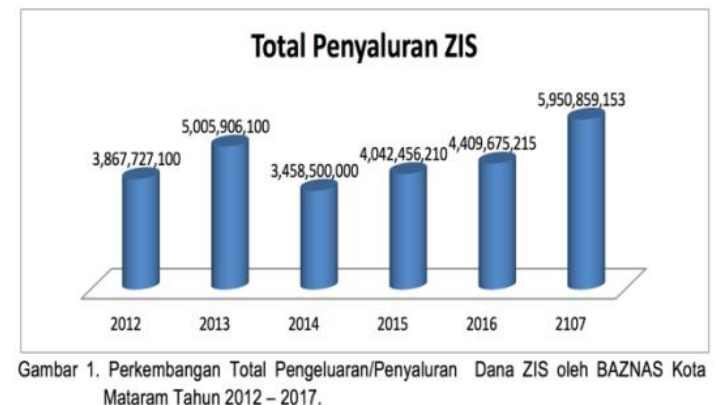

Pengeluaran mapun penyaluran telah memiliki pos - pos tertentu sebagaimana peruntukannya. Dana yang besumber dari bantuan Pemerintah Kota
Mataram dipergunakan untuk kegiatan operasional BAZNAS Kota Mataram sementara penerimaan yang berasal dari ZIS dan lainnya diperutukkan bagi orang orang yang berhak menerimanya. Pergerakan total pengeluaran mengalami gelombang naik turun dari tahun 2012 2017. Yang menarik adalah pengeluaran pada tahun 2017 yang paling banyak, padahal jumlah penerimaannya mengalami penurunan dari tahun 2017. Hal ini disebabkan oleh berbagai faktor terutama kondisi sosial ekonomi yang menyertai perjalanan tahun 2017 sehingga menyebabkan bertambahnya orang orang yang berhak menerima ZIS dan juga biaya operasional yang juga bertambah. Jenis - jenis pengeluaran yang dikeluarkan oleh BAZNAS Kota Matarm umumnya terdiri dari 3 kegiaran yaitu : (1) Pengeluaran/Penyaluran ZIS Penggunaan Dana Pengelola; Penggunaan Bagi Hasil /Jasa Bank.

Khususnya pengeluaran untuk Dana ZIS diperuntukkan kepada golongan golongan (ashnaf) yang berhak menerimanya (mustahiq) seperti Fakir, miskin, Amil, Mualaf, Fisabilillah, Ibnu Sabil, orang yang berutang, sedangkan untuk budak tidak ada. Selain itu pengeluaran dana ZIS ini tertuju pula untuk bantuan Bencana Alam, Bantuan Pendidikan, Bantuan Pengobatan, Bantuan Tempat Ibadah, Bantuan untuk lembaga keagamaan, bantuan untuk beasiswa serta santunan untuk Manusia Lansia terlantar. Penyaluran khusus dari dana ZIS setiap tahunnya selalu berubah baik peruntukkannya maupun besarnya. Misalnya pada tahun 2016, bentuk bentuk penyaluran di atas dikelompokkan ke dalam beberapa bidang yaitu : (1)BidanG ekonomi, (2) Bdiang pendidikan, (3) Bidang Dakwah; (4) Bidang Kesehatan; dan (5) Bidang Sosial Kemanusiaan. Alokasi dari masing masing bidang ini terlihat berikut : 
Tabel 2. Jumlah Penyaluran Dana Zakat, Infaq Dan Shadaqah (ZIS) Berdasarkan Ashnaf oleh BAZNAS Kota Mataram Tahun 2012- 2017

\begin{tabular}{|c|c|c|c|}
\hline No & Ashnaf & Penyaluran (Rp) & Persentase (\%) \\
\hline 1 & Fakir Miskin & 2.527 .363 .300 & 57,00 \\
\hline 2 & Amil & 454.611 .915 & 10,00 \\
\hline 3 & Muallaf & 86.700 .000 & 2,00 \\
\hline 4 & Riqab & 0 & 0 \\
\hline 5 & Gharimin & 0 & 0 \\
\hline 6 & Fiisabilillah & 1.335 .200 .000 & 30,00 \\
\hline 7 & Ibnu Sabil & 5.800 .000 & 1,00 \\
\hline & Jumlah & 4.409 .675 .215 & 100 \\
\hline
\end{tabular}

Sumber : Baznas Kota Mataram, 2016

Berdasarkan tabel di atas, dana yang disalurkan untuk ashnaf Fakir dan Miskin merupakan yang terbesar sebesar 57, 00 persen diikuti oleh Fiisabilillah sebesar 30,00 persen dan yang terkecil untuk Ibnu Sabil sebesar 1,00, sedangkan untuk Riqab dan Gharimin tidak mendapat bagian untuk disalurkan. Besarnya pendistirubsian untuk fakir miskin merupakan hal yang wajar mengingat masih banyak penduduk kota Mataram yang kehidupannya berada di bawah garis kemiskinan. Dengan adanya dana ZIS diharapkan akan mampu mengurangi penduduk miskin tersebut. Selanjutnya pendisitribusian berdasarkan anshaf ini dikelompokan dalam bidang bdiang yang besarnya terlihat berikut .

\begin{tabular}{|c|c|c|c|}
\hline No & Ashnaf & Penyaluran (Rp) & Persentase $(\%)$ \\
\hline 1 & Ekonomi & 761.000 .000 & 17,00 \\
\hline 2 & Pendidikan & 217.950 .000 & 5,00 \\
\hline 3 & Dakwah & 1.028 .800 .000 & 23,00 \\
\hline 4 & Kesehatan & 41.000 .000 & 1,00 \\
\hline \multirow[t]{2}{*}{5} & Sosial Kemanusiaan & 2.360 .295 .251 & 54,00 \\
\hline & Jumlah & 4.409 .675 .215 & 100,00 \\
\hline
\end{tabular}

Penyaluran dana ZIS untuk masing - masing bidang ini akan semakin bertambah seiringa dengan semakin banyaknya dana ZIS yang mampi dihimpun oleh BAZNAS Kota Mataram. Namun demikian, tidak semua dana yang diterima atau dihimpun oleh BAZNAS Kota Mataram disalurkan semua pada tahun berjalan. Berdasarkan data masih ada dana yang belum tersalurkan semua dan menjadi saldo tahun berjalan serta dijadikan penerimaan pada tahun berikutnya. Banyaknya saldo sisa terlihat dalam tabel berikut.
Tabel 4. Jumlah Penerimaan, Penyaluran Dan Selisih Dana Zakat, Infaq dan Shadaqah (ZIS) Yang Dikelola Oleh BAZNAS Kota Mataram Tahun 2012 - 2017

\begin{tabular}{|c|c|c|c|}
\hline Tahun & $\begin{array}{c}\text { Penerimaan } \\
\text { (Rp) }\end{array}$ & $\begin{array}{c}\text { Penyaluran } \\
\text { (Rp) }\end{array}$ & $\begin{array}{c}\text { Selisih } \\
\text { (Rp) }\end{array}$ \\
\hline 2012 & 5.3132 .019 .432 & 3.867 .727 .100 & 1.464 .292 .332 \\
\hline 2013 & 7.079 .249 .243 & 5.005 .906 .100 & 2.073 .343 .143 \\
\hline 2014 & 6.658 .641 .059 & 3.458 .500 .000 & 3.200 .141 .059 \\
\hline 2015 & 7.370 .958 .144 & 4.042 .456 .210 & 3.328 .501 .934 \\
\hline 2016 & 7.835 .705 .161 & 4.409 .675 .215 & 3.426 .029 .946 \\
\hline 2017 & 6.444 .496 .859 & 5.950 .859 .153 & 493.637 .706 \\
\hline \multicolumn{2}{|l}{} \\
\hline
\end{tabular}

Selisih dana penerimaan dan penyaluran merupakan komponen penerimaan untuk tahun berikutnya. Tersisanya dana baik dari ZIS maupun penerimaan lainnya membawa implikasi dari kemampuan BAZDA Kota Mataram dalam pengelolaan keuangannya. Dana penerimaan yang tidak dapat disalurkan terutama yang berasal dari penerimaan ZIS dapat menimbulkan berbagai asumsi karena adanya pemahaman yang berbeda. Perbedaan ini tentunya didasarkan pada anggapan bahwa dana ZIS harus didistribusikan semua karena banyak yang membutuhkan, sementara ada juga yang berpandangan boleh. Hal ini akan menjadi tugas dari BAZNAS Kota Mataram untuk memberikan penjelasan yang faktual terhadap dana yang tersisa tersebut, meskipun dalam laporan keuangan saldo sisa merupakan suatu keniscayaan.

\subsection{Perkembangan/Pertumbuhan \\ Dana ZIS Yang Dihimpun Dan Disalurkan Oleh BAZNAS Kota Mataram tahun 2012 - 2017. \\ Pergerakan pertumbuhan} penerimaan ZIS berbeda dengan pergerakan pertumbuhan penerimaan ZIS berfluktuatif. Pada tahun 2013 pertumbuhan cukup tinggi, dan menurun pada tahun 2014. Penurunan ini masih lebih tinggi dibanding pertumbuhan total penerimaan. Hal ini bermakna bahwa meski terjadi penurunan total penerimaan, namun perrubahan penerimaan ZIS masih lebih tinggi dari perubahan total penerimaan. Namun pertumbuhan yang tinggi tidak dapat dipertahankan, karena 


\section{Elastisitas - Jurnal Ekonomi Pembangunan \\ Vol. 1 No. 1, (2019), 37 - 53}

pada tahun 205 - 2017 terur mengalami penurunan hingga mencapai negatif 1,82 persen.

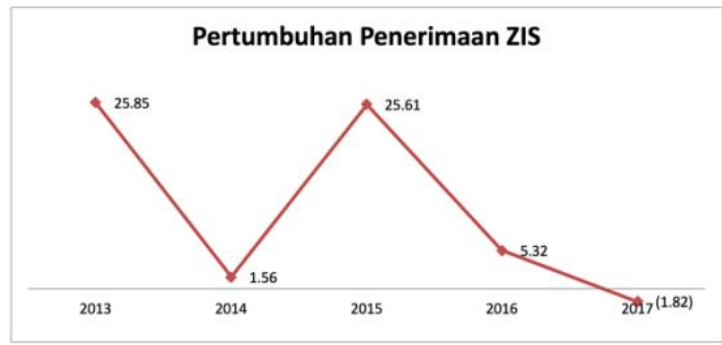

Pergerakan Pertumbuhan penerimaan ZIS menunjukkan kinerja BAZNAS Kota Mataram selama 6 tahun mengalami nak dan turun. Hal ini sejalan dengan kemampuan BAZNAS mengumpulkan dana ZIS yang secara nominal juga mengalami fluktuasi. Penerimaan sejak tahun 2015 -2016 meski mengalami peningkatan tetapi pertumbuhannya menurun. Yang bermakna bahwa ikhtiar yang dilakukan oleh BAZNAS Kota Mataram belum maksimal. Pada tahun 2017 mengalami penurunan yang disebabkan berkurangnya muzaki yang berada pada salah sat SKPD khususnya yang berhubungan dengan dunia pendidikan. Pada tahun 2017 terdapat kebijakan pemerintah yang menarik kewenangan pemerintah daerah yang berkenaan dengan guru- guru maupun pegawai SMTA diambil alih oleh pemerintah Provinsi. Dengan sendirinya muzaki yang berada di SKPD tersebut berpindah ke provinsi yang menyebabkan perolah ZIS mengalami penurunan.

Penyaluran merupakan kegiatan mendistribusikan dana yang diterima oleh BAZNAS kota Mataram diberikan kepada berbagai pihak yang menerimanya. Pergerakan pertumbuhan penyaluran pada awalnya mengikuti pergerakan pertumbuhan penerimaan yang semula tinggi kemudian turun dan terus menaik hingg tahun 2017 dengan pertumbuhan tertinggi sebessar 34,95 persen.

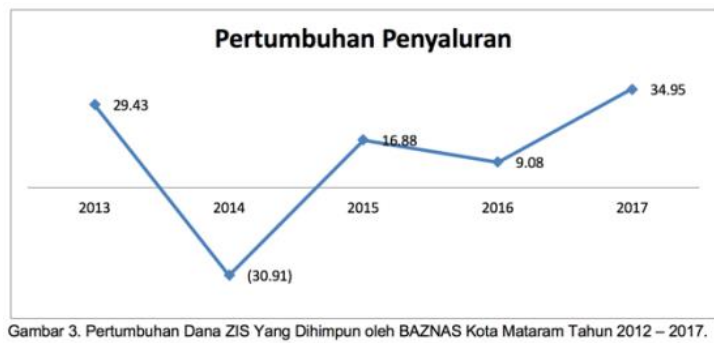

Pergerakan yang terus menaik ini mengindikasikan bahwa pengeluaran terhadap dana - dana rutin dan penyaluran dana ZIS terus mengalami pertumbuhan positif. Pertumbuhan penyaluran ini tidak terlepas dari adanya keinginan dari BAZNAS untuk meningkatkan kualitas kehidupan para mustahiq tidak hanya dalam bentuk konsumtif namun juga melalui kegiatan pemberdayaan. Untuk mewujudkan hal ini, beberapa program pemberdayaan spesifik yang dilakukan oleh BAZNAS Kota Mataram. Beberapa program yang akan dan telah dilakukan oleh BAZNAS Kota Mataram berkenaan dengan pemberdayaan adalah : (1) Program Mataram Peduli, (2) Program Mataram Sejahtera, (3) Program Mataram cerdas, (4) Program Mataram Sehat, (5) Program Mataram Taqwa.

Berdasarkan 5 program ini telah disalurkan dana yang bersumber dana yang dihimpun oleh BAZNAS Kota Mataram sesuai dengan komponen komponen yang berada dalam setiap program tersebut. Adanya penyaluran di dasarkan pada berbagai program, dapat diketahui secara pasti golongan - golongan masyarakat yang berhak menerima dan tidak akan adamustahiq yang akan menerima sekaligus 2 program. Inilah manfaat langsung yang dirasakan oleh muatahiq bila ZIS dikelola secara resmi oleh suatu lembaga pengelola dana Zakat, Infaq dan Shadaqah (ZIS).

Dana ZIS yang dikeluarkan oleh muzaki yang disalurkan oleh lembaga pengelola ZIS kepada masyarakat yang berhak menerimanya, merupakan mata rantai 


\section{Elastisitas - Jurnal Ekonomi Pembangunan \\ Vol. 1 No. 1, (2019), 37 - 53}

yang menghubungkan antara muzaki dan mustahiq. Muzaki merasa puas terhadap kinerja BAZNAS karena hak dan kewajibannya telah sampai kepada yang behak menerimanya. Sisi lain, mustahiq merasa berbahagia karena adanya rasa kepedulian dari orang yang mampu terhadap sesama manusia yang kondisi kehidupan sosial ekonominya masih berada dalam katagori tidak mampu. Manusia yang mampu benar - benar mengimpimentasikan berbagai firman Allah yang terdapat di dalam Al-Qur'an tentang perintah mengeluarkan harta kekayaan yang dimiliki. Salah satu perintah Allah terdapat dalam surat AlHasar ayat 7 : supaya harta itu jangan beredar di antara orang-orang kaya saja di antara kamu.

Kesadaran yang makin tinggi dari muzaki untuk mengeluarkan zakat maupun yang belum tergolong muzaki yang mengeluarkan infaq, shadaqah maupun ubadah lainnya akan semakin membuka peluang bagi BAZNAS untuk mengelola dana tersebut dalam bentuk dsitribusi harta. Orang yang benar - benar telah memahami akan pentingnya berzakat akan digolongkan sebagai salah satu ciri orang yang beruntung sebagaimana Allah berfirman dalam Surat Al-Mukminun ayat 4:

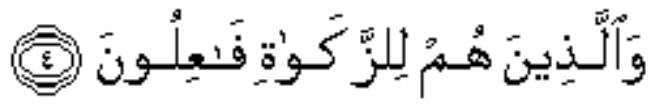

artinya dan orang-orang yang menunaikan zakat,. Dengan demikian, keuntungan tidak saja dilihat dari sisi materi melainkan dari sisi spritual. Jika hal ini telah dipahami oleh sebahagian besar umat muslim, maka zakat sebagai sumber utama dalam sistem keuangan Islam akan semakin berkembang dan menjadi piranti utama pula dalam proses pembangunan bangsa.

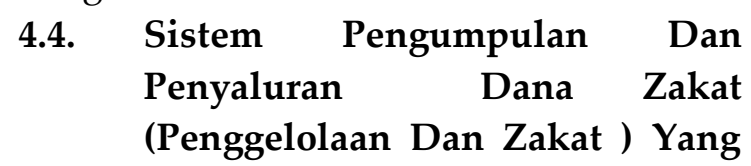

\section{Dilakukan Oleh BAZNAS Kota Mataram.}

Sistem pengelolaan zakat merupakan koordinasi yang terintegrasi antara Lembaga Pengelola Zakat (BAZNAS dan LAZ) Pemerintah maupun Masyarakat, baik dalam program pengumpulan, pendistiribusian, dan pengayagunaan, guna dapat meningkatkan efektivitas dan efisiensi pelayanan pengelolaan zakat yang bertujuan untuk mewujudkan kesejahteraan masyarakat dan penanggulangan kemiskinan (Kusnandar, 2017). Sistem Pengelolaan Zakat harus dilaksanakan secara profesional, transparansi serta harus menjunjung tinggi nilai kebersamaan dan kesatuan pendapat, sehingga roda organisasi dapat mewujudkan harapan sesuai dengan visi dan misinya. Koordinasi dan integrasi sangat penting dalam mengelola suatu lembaga termasuk dalam pengelolaan Zakat.

Sistem Pengelolaan Zakat yang dipraktekkan oleh BAZNAS Kota Mataram adalah merealisasikan berbagai tahap kegiatan yang telah disusun yaitu (Kusnandar, 2018) : (1) Segi Perencanaan; (2) Segi Organisasi; (3) Segi Pelaksanaan; (4) Segi Pengawasan; (5) Segi Pelaporan. Sistem pengelolaan zakat yang berjalan dengan koordinasi yang baik, tercipta komunikasi dan integrasi yang baik akan mampu menghantarkan roda organisasi ini berjalan sesuai dengan harapan umat yang memberikan kepercayaan untuk mengelola dana zakat, infaq maupun shadaqahnya. Terjadi komunikasi yang baik, terbuka antara Amil Zakat, Muzaki dan Mustahiq akan semakin memperluas wilayah dan sasaran yang dituju oleh organisasi ini. Sistem pengelolaan yang telah berjalan akan semakin melebar bila tumbuh jaringan yang kuat, sehingga eksistensi salah satu lembaga umat Islam ini semakin berkibar dan bersinar. 


\section{Elastisitas - Jurnal Ekonomi Pembangunan \\ Vol. 1 No. 1, (2019), 37 - 53}

V. KESIMPULAN DAN SARAN

\subsection{Kesimpulan}

1. Badan Amil Zakat Nasional (BAZNAS) Kota Mataram berfungsi sebagai lembaga yang mengelola dana Zakat, Infaq dan Shadaqah (ZIS) dengan bertindak sebagai amil yang menerima dan menyalurkan dana tersebut kepada pihak yang berhak menerimanya.

2. Wujud dari Pengelolaan Dana Zakat, Badan Amil Zakat Nasional (BAZNAS) menuangkan dalam bentuk Laporan Keuangan yang dibuat setiap tahun dibawah pengawasan pihak internal maupun eksternal dari Akuntan Publik.

3. Realisasi penerimaan dana zakat dari tahun 2012 - 2016 mengalami peningkatan. Sumber dana zakat yang dihimpun berasal dari ZIS setiap pegawai SKPD yang berada di Kota Mataram, muzakki perorangan dan Badan Usaha. Peningkatan penerimaan dana ZIS yang dihimpun mencerminkan kepercayaan masyarakat terhadap BAZNAS Kota Mataram terus mengalami peningkatan.

4. Realisasi zakat yang dapat dihimpun masih lebih rendah dari potensi yang ada, dan hanya mampu dihimpun sekitar 30 persen dari potensi zakat yang ada dan 74 persen dari target yang direncanakan. BAZNAS Kota Mataram pada tahun 2017 mampu merealisasikan penerimaan Zakat sebesar 130,10 persen dari yang ditargetkan.

5. Dana ZIS yang disalurkan oleh BAZNAS Kota Mataram terus mengalami peningkatan, seiring dengan semakin banyaknya orang yeng berhak menerima dan bervariatifnya jenis dan bentuk penyaluran. telah disampaikan kepada golongan yang berhak menerimanya melalui 5 program yang dicanangkan oleh BAZNAS Kota Mataram.

6. Bentuk pengeluaran yang dilakukan oleh BAZNAS Kota Mataram adalah Pengeluaran/Penyaluran ZIS, Penggunaan Dana Pengelola, Penggunaan Bagi Hasil /Jasa Bank

7. Sistem Pengelolaan Zakat oleh BAZNAS Kota Mataram telah mengikuti petunjuk yanfg diatur dalam UU Zakat No 23 Tahun 2011 dengan melakukan konvigurasi sesuai dengan kondisi yang terjadi di masing - masing daerah.

8. Pertanggungjawaban pengelolaan keuangan dalam bentuk laporan keuangan pada tahun 2017 mendapat prestasi wajar dari lembaga akuntan publik.

\subsection{Saran - saran}

1. Disarankan kepada BAZNAS Kota Mataram untuk terus mempertahankan program yang sudah berjalan dengan tidak menutup kemungkinan dikembangkan program prgoram baru sesuai dengan kondisi yang terjadi pada masa kini.

2. BAZNAS Kota Mataram tanpa mengenal lelah terus menggali potensi dana zakat yang ada sekaligus menjemput potensi potensi zakat yang belum dapat dihimpun.

3. Mempertahankan prestasi kinerja pengelolaan keuangan yang telah diraih dengan tetap memperhatikan kualitas dan ketepatan dalam menyusunkomponen komponen yang disyaratkan dalam laporan keuangan. 


\section{Elastisitas - Jurnal Ekonomi Pembangunan \\ Vol. 1 No. 1, (2019), 37 - 53}

\section{DAFTAR PUSTAKA}

Ali, Muhammad Daud, 1988, Sistem Ekonomi Islam Zakat Dan Wakaf, Universitas Indonesia, Jakarta.

Ash-Shiddieqy, Hasbi, 1991, Pedoman Zakat, Bulan Bintang, Jakarta.

Badan Pusat Statistik, 2013 - 2018, Kota Mataram Dalam Angka, Mataram.

Berita Resmi Statistik, 2017, Keadaan Ketenagakerjaan NTB Agusrtus 2017, BPS NTB, 6 Nopember 2017.

BAZNAS Mataram, Laporan Tahunan Pengelolaan Zakat, Infaq dan Shadaqah (ZIS) Tahun 2012 - 2017, Mataram.

Doa, M. Djamal 2001 , Membangun Ekonomi Umat Melalui Pengelolaan Zakat Harta, Nuansa Madani, Jakarta.

$$
\text { 2005, Menggagas }
$$

Pengelolaan Zakat, Nuansa Madani, Jakarta.

Fakhrudin, 2008, Fiqh dan Manajemen Zakat di Indonesia, UIN Malang Prress, Malang.

Kuncoro, Mudradjat, 2013, Mudah Memahami dan Menganalisis Indikator Ekonomi, UPT STIM YKPN, Yogyakarta.

Kusnandar, Heri, 2018, Sistem Pengelolaan Zakat dalam Suara Qalbu Edisi Awal tahun 2018, BAZNAS Kota Mataram, Mataram.
Mahmudi, 2016, Analisis Laporan Keuangan Pemerintah Daerah, UPT STIM YKPN, Yogyakarta.

Najmuddin, 2011, Manajemen Keuangan dan Aktualisasi Syr'iyyah Modern, Andi., Yogyakarta.

Prastowo, Dwi, 2015, Analisis Laporan Keuangan Konsep dan Aplikasi, UPT STIM YKPN, Yogyakarta.

Qardawi, Yusuf, 1996, Hukum Zakat (terj), Kerjasama Utera Antar Nusa dan Mizan, Bandung. 2005, Spektrum Zakat Dalam Membangun Ekonomi Kerakyatan, ZIKRUL HAKIM, Jakarta.

Tambunan, Tulus T.H, 2014, Perekonomian Indonesia Kajian Teoritis dan Analisis Empiris, Ghalia Indonesia, Jakarta.

Wibisono, Yusuf, 2015, MengelolaZakat Indonesia, Diskursus Pengelolaan Zakat Nasional dari Rezim UndangUndang Nomor 38 Tahun 1999 ke Rezim Undang - Undang Nomor 23 Tahun 2011, PrenadaMedia Group, Jakarta.

Wijayanti, Anita dan Hendrik, 2008, Mukzizat Zakat, Mengungkap Rahasia Menakjubkan Dibalik Perintah Zakat Tinjauan Syariat dan Medis, Pustaka Iltiza, Solo. 